\title{
Access to Microfinance Institutions and Official Banks and the Impact on Small Business in Togo
}

\author{
Koffi Sodokin ${ }^{1}$ \\ ${ }^{1}$ Research and Training Center in Economics Sciences and Management (CERFEG), FaSEG, Univesity of Lome, \\ Togo \\ Correspondence: Koffi Sodokin, Research, and Training Center in Economics Sciences and Management \\ (CERFEG), FaSEG, Univesity of Lome, Togo. Tel: 022-890-981-405.
}

Received: November 3, 2021

Accepted: November 25, 2021

Online Published: November 30, 2021

doi:10.5539/ijef.v14n1p46

URL: https://doi.org/10.5539/ijef.v14n1p46

\begin{abstract}
This paper aims to analyze the impact of access to a microfinance institution and official banks on households' small businesses in Togo. The study uses data from the Harmonized Survey of Household Living Conditions conducted in 2019 by the National Institute of Statistics, Economic and Demographic Studies on 27,480 individuals and 6,171 households in Togo. The paper uses propensity score matching. The results show that credit access improves households' small businesses, particularly in Togo's agriculture sector.
\end{abstract}

Keywords: household small business, microcredit, Official Bank Credit, small business

\section{Introduction}

There is a growing interest in the economic literature on the importance of microcredit, particularly its economic development role. Microfinance's importance justifies rigorous empirical work to assess the net impact of access to microcredit on entrepreneurial behavior and household welfare. Among the work that exists, from both microeconomic and macroeconomic perspectives, a significant number is increasingly devoted to understanding the functioning of the microcredit market, its imperfections, and credit rationing. Also, recent analyses have focused on the microeconomic and macroeconomic impacts of microfinance in an integrated environment (Amendariz \& Labie, 2011; Alimukhamedova, 2019). However, studies from a macroeconomic perspective are relatively more recent due to a lack of data (Imai et al., 2012; Kamel \& Ben, 2018). Thus, most studies on the impact of microcredit have focused more on the microeconomic aspect, with mixed results.

In this paper, I focus on the impact of access to credit (microcredit and bank credit) on household business in Togo. I organize the rest of the article into five sections. Section 2 presents the literature review. In section 3, I describe the methodology and the estimation techniques. Section 4 presents the descriptive statistics and some characteristics of credit demand in Togo throughout the survey. The estimates using the propensity score matching method and the impact of credit access on household business are presented in section 5. In section 6, I conclude.

\section{Review of the Literature}

\subsection{Access to Credit and Impact on the Reduction of Poverty}

According to the World Bank's World Development Report, 2000/2001 on Strategic Actions for Poverty Reduction, effective participation of micro and small enterprises in market activities through access to credit is an appropriate solution. Unfortunately, most developing countries' households, especially in Africa, have no access to the traditional financial system because it is still incomplete and deficient (Li et al., 1998). The absence of appropriate formal financial services had long led the people to the informal financial sector like the Rotating Savings and Credit Associations and the usurious moneylender, with very prohibitive interest rates (Belwal et al., 2012). Since microcredit focuses primarily on the poor in developing countries, its services would undoubtedly reduce income poverty and inequality (Sodokin, 2007).

Studies have highlighted the positive link between high microcredit intensity and low poverty levels (Imai et al., 2012). From a macroeconomic perspective, the number of studies on microcredit's impact remains limited (Sodokin \& Donou-Adonsou, 2010; Couchoro \& Gbandi, 2018, Imai et al., 2012, Ahlin et al., 2010). Couchoro and Gbandi (2018) from a macroeconomic perspective, highlight the impact of microcredit on poverty in terms 
of human development and multidimensional poverty in the Economic Community of West African States countries (ECOWAS). They show, from panel data estimations, that microcredit contributes to the decline of multidimensional poverty. Bangoura et al. (2016) based on a panel of 52 developing countries show that microfinance improves the poor's income and reduces inequalities. Donou-Adonsou and Sylwester (2016) applied the instrumental variables approach to a panel of 71 developing countries over 2002-2011. The results show that the banking system's development has helped reduce poverty in developing countries over this period, while microcredit does not impact poverty. Imai et al. (2012) examined the links between microfinance and the poverty rate, especially the Foster-Greer-Thorbecke poverty class index. Their results show that a high level of gross loan portfolios per capita of Microcredit institutions is associated with low poverty rates. Most of the studies that have dealt with the impact of microcredit are microeconomic level. Some of these studies positively impact poverty, while others show no effect or mixed results.

Furthermore, several studies have tried to establish the relationship between microfinance and poverty reduction in this case. Belwal et al. (2012) find, by using a quantitative analysis based on questionnaires and interviews, that microfinance impact positively income and savings of women entrepreneurs in Addis-Ababa. Based on randomized controlled trials, some impact studies (Banerjee et al., 2009) have produced mixed results and skepticism about microfinance effects. Surveys in Bangladesh show that microfinance's impact on poverty is more pronounced among impoverished households than moderate poverty (Khandker, 2005). Other studies provide country-specific evidence on the poverty reduction potential of microfinance, e.g., Mosley (2001) in Bolivia, Bruhn, and Love (2014), Nader (2008) in Cairo (Egypt). Agbola et al. (2017) find a mildly positive impact of microfinance on poverty reduction and wellbeing in the Philippines. Raihan et al. (2017) analyzes the macroeconomic impact of microfinance in Bangladesh and find that microfinance has affected the real economy. He finds that microfinance contributes to country GDP between $8.9 \%$ and $11.9 \%$; the rural GDP contribution is even higher.

\subsection{Microcredit Market and Credit Rationing}

Some research has drawn attention to the rural credit market (Meyer \& Nagarajan, 2000). The authors show that the rural credit market is subject to high transaction costs and lack of collateral, such as when borrowers do not have legal title to their land. Quach and Mullineux (2006) suggest that combining these analyses should raise questions about credit institutions' determinants of borrower choice. For instance, Kochar (1997), Duong and Izumita (2002), Zeller (1994) have used various approaches to address the issue of rural credit. Their findings suggest that formal and informal lenders ration the supply of credit (Zeller, 1994) while reputation, dependency ratio, and the amount of credit requested are the determinants of credit rationing (Pham \& Izumita, 2002). In other words, poor households are more likely to face credit rationing in the market.

Other work has also analyzed the determinants of the amounts of credit issued. Pitt and Khandker (1996) and Yadav et al. (1992) showed that credit's demand and supply are the theoretical determinants of credit granted. Concerning empirical work, Pham and Izumita (2002) have shown that farmers' total value was very decisive in their formal credit access. Other household characteristics such as age, level of education, residence, and competitive environmental characteristics explain household access to credit (Pitt \& Khandker, 1996; Khandker \& Faruqee, 2003).

\section{Econometric Model and Methodology}

The method's idea is to match treated households with untreated ones with similar values for the characteristics that we have found to be the determinants of credit access in the previous section. We use the Propensity score matching (PSM) framework to take into account the selection bias. According to the approach of Rubin (1973), for each household $i$, with $i=1,2, \ldots, N$, the treatment effect, $\Delta_{i}$, can be defined as the difference between «treated» and «untreated»:

$$
\Delta_{i}=Y_{1 i}-Y_{0 i}
$$

Where $Y_{1 i}$ and $Y_{0 i}$ represents the potential outcomes for treated and non-treated households, respectively. For each unit (households) $i$, it's only possible to observe one result, while the other is the counterfactual scenario that cannot be obtained from the data.

Following Sodokin (2021), Sodokin and Nyatefe (2021), Ghalib and Al-Hattami (2015) replicated by (Mora-Rivera et al., 2019), I can modify equation 1 in such a way to allow estimating the average treatment effect on the treated (ATT) that we can formally express as follow:

$$
A T T=(\Delta \mid Z=1)=E\left(Y_{1} \mid Z=1\right)-E\left(Y_{0} \mid Z=1\right)
$$

With ATT, the difference between the potential outcome with and without treatment for households that receive 
treatment and $Z$, an indicator variable of the state $(Z=1$ when the treatment is received and $Z=0$ when not).

As stated by Sodokin (2021), one problem in equation (2) is unobservability. In fact, without additional assumptions, I will not be able to estimate $E\left(Y_{0} \mid Z=1\right)$, which indicates the hypothetical outcome that would have been obtained if the treated had not received government cash transfers. I can rewrite equation 2 like follow:

$$
E\left(Y_{1} \mid Z=1\right)-E\left(Y_{0} \mid Z=1\right)=A T T-\left[E\left(Y_{0} \mid Z=0\right)-E\left(Y_{0} \mid Z=1\right]\right.
$$

Where $E\left(Y_{1} \mid Z=1\right)$ and $E\left(Y_{0} \mid Z=0\right)$ can be estimated, but these do not provide the ATT. In addition to that, I can only evaluate this effect when the bias is zero, i.e., $E\left(Y_{0} \mid Z=1\right)-E\left(Y_{0} \mid Z=0\right)=0$. However, when using non-experimental data, as in our case, this condition generally does not hold because the variables that explain the participation decision also contribute to determining the outcome variable (Mora-Rivera et al., 2019). Consequently, treated households' outcomes will be different even in the absence of the treatment, leading to a self-selection bias problem.

I use the propensity score matching method to deal with such bias and obtain unbiased and robust ATT estimates (Abadie \& Imbens, 2011). This method's backbone is to identify a sufficient number of candidates that closely resemble the beneficiary households in the control group. Based on the estimated propensity score, we will evaluate credit access's impact on households' investment and social resilience. Two fundamental assumptions are required when using the PSM method: Exogeneity of the treatment and overlap.

The first exogeneity assumption implies that the difference in potential outcomes (access to credit and the expansion of economic activities) - with and without treatment - is due only to the treatment conditional on a covariate vector $(\mathrm{X})$. Moreover, the covariate set in this vector is not affected by the treatment, and it's assumed that it has been captured in the model, which means that there are no omitted variables. Formally, this first assumption can be expressed as follows:

$$
\left\{Y_{0}, Y_{1}\right\} \perp Z \mid X
$$

According to (Ghalib et al., 2011), the overlap assumption assumes the perfect predictability of participation on vector X. It guarantees that all business owners with the same characteristics within the sample have a positive probability of being treated or untreated. Formally, it can be expressed as follows:

$$
0<P(Z=1 \mid X)<1
$$

The ATT can now be estimated using Propensity Score Matching, which solves dimensionality problems when X has too many components. Rosenbaum and Rubin (1983) defined propensity scores as a function that estimates the probability of receiving the treatment given the vector of covariates $\mathrm{X}$, previously observed:

$$
\theta(X)=P(Z=1 \mid X)
$$

$\mathrm{X}$ is summarizing into a single number $\theta$. To estimate $\theta$, one can use the probit or logit model to predict the probability that a household has access to credit based on its characteristics. According to Rosenbaum and Rubin (1983), we can show that the propensity score estimated satisfies the exogeneity and overlap assumption. Therefore, the PSM estimator of ATT is nore biased and can be written as follows:

$$
A T T^{P S M}=E_{\theta(X) \mid Z=1}\left[E\left(Y_{1} \mid Z=1, \theta(X)\right)-E\left(Y_{0} \mid Z=1, \theta(X)\right)\right]
$$

Becker and Ichino (2002), Cameron and Trivedi (2010) listed several matching algorithms that can be used to estimate the ATT. In our case, we report the results for four of them: Nearest neighbor, stratification, radius, and kernel matching. This allows us to compare the results and test the robustness of the estimated impacts of credit access on households' investment in the non-farm business.

The dependent variable describing the demand or supply of credit by a household $i$ is a binary variable taking the value 1 if the household is applying for credit and 0 otherwise. Typically, these forms are estimated by a Logit model or a Probit model. Here I estimate probabilities using a Probit model, assuming that the choice functions follow a normal law. Let $\mathrm{G}$ be the distribution function of the standardized normal distribution law which is written in the form:

$$
G(z)=\phi(z) \equiv \int_{-\infty}^{z} \phi(v) d v
$$

where $\emptyset(v)=(2 \pi)^{-1 / 2} \exp \left(-z^{2} / 2\right)$ is the density of the standard normal distribution.

The latent variable model $\left(y^{*}\right)$ subjacent is written as:

$$
y^{*}=\beta_{0}+x_{i} \beta+e, y=1\left[y^{*}>0\right]
$$

With $y^{*}$ the unobserved variable for which the proxy used is the demand for credit, $x_{i}$ a vector of explanatory 
variables, $\beta_{0}$ and $\beta i$ are the parameters to be estimated and $e$ the error term independent of $x_{i}$, rotationally balanced at 0 and normally distributed. $y$ is worth the value of 1 if $y^{*}>0$ and zero if $y^{*} \leq 0$ and the probability of response under the above assumptions can be written as follows:

$$
P(y=1 \mid x)=P\left(y^{*}>0 \mid x_{i}\right)=G\left(\beta_{0}+x_{i} \beta i\right)
$$

I rewrite the empirical model as follows:

$$
\begin{gathered}
P(\text { Credit }=1 \mid x)=G\left(\beta_{0}+\beta_{1} \text { age }+\beta_{2} \text { age square }+\beta_{3} \text { savings }+\beta_{4} \text { land }+\beta_{5} \text { association }+\right. \\
\beta_{6} \text { education }+\beta_{7} \text { sizer }+\beta_{8} \text { regions }+\beta_{9} \text { rural }+\beta_{10} \text { gender }+\beta_{11} \text { sick }+ \\
\beta_{12} \log (\text { income })+\beta_{13} \text { marital statut }+\varepsilon_{i}
\end{gathered}
$$

\section{Data Collection and Descriptive Analysis}

We use the Harmonized Household Living Conditions Survey (EHCVM) data, collected by the National Institute of Statistics Economic and Demographic Studies (INSEED) in 2019. The EHCVM survey covered all the Togo regions and was conducted in rural and urban areas using a sample of 27480 individuals and 6171 households. The survey also analyzed monetary poverty, poverty based on most households' living conditions, and potential poverty while establishing a correlation.

Table 1 shows the descriptive statistics of variables used in the empirical analysis. According to the data, the average age of household heads is about 44 years. The statistics in the table also show that these households own

\begin{tabular}{|c|c|c|c|c|c|c|}
\hline & & (1) & (2) & (3) & $(4)$ & (5) \\
\hline Variables & Description & $\mathrm{N}$ & Mean & $\mathrm{Sd}$ & Min & Max \\
\hline Household Size & The number of household members & 5,806 & 4.430 & 2.719 & 1 & 31 \\
\hline Household Age & $\begin{array}{l}\text { Age of the household head: Number of years from the birth to the date of } \\
\text { the survey }\end{array}$ & 5,806 & 44.39 & 14.91 & 15 & 105 \\
\hline $\begin{array}{l}\text { Primary } \\
\text { education }\end{array}$ & $\begin{array}{l}\text { Take value } 1 \text { if the household head has a primary level of education and } 0 \\
\text { otherwise }\end{array}$ & 5,806 & 0.252 & 0.434 & 0 & 1 \\
\hline $\begin{array}{l}\text { Secondary } \\
\text { education }\end{array}$ & $\begin{array}{l}\text { Take value } 1 \text { if the household head has a secondary level of education } \\
\text { and } 0 \text { otherwise }\end{array}$ & 5,806 & 0.316 & 0.465 & 0 & 1 \\
\hline $\begin{array}{l}\text { University } \\
\text { education }\end{array}$ & $\begin{array}{l}\text { Take value } 1 \text { if the household head has a high level of education and } 0 \\
\text { otherwise }\end{array}$ & 5,806 & 0.0539 & 0.226 & 0 & 1 \\
\hline Age square & $\begin{array}{l}\text { The square of the household number of years from birth to the date of the } \\
\text { survey }\end{array}$ & 5,806 & 2,193 & 1,476 & 225 & 11,025 \\
\hline Maritime & & 5,806 & 0.153 & 0.360 & 0 & 1 \\
\hline Lome & & 5,806 & 0.165 & 0.371 & 0 & 1 \\
\hline Plateau & Households residence region (Lome, maritime, plateau, central kara, & 5,806 & 0.180 & 0.384 & 0 & 1 \\
\hline Central & savane)* & 5,806 & 0.133 & 0.339 & 0 & 1 \\
\hline Kara & & 5,806 & 0.184 & 0.387 & 0 & 1 \\
\hline Rural & Takes value 1 if the household lives in a rural area and 0 if in a town & 5,806 & 0.634 & 0.482 & 0 & 1 \\
\hline Sick & $\begin{array}{l}\text { Take value } 1 \text { if a household has been sick and ceased working during the } \\
\text { week before the survey and } 0 \text { otherwise. }\end{array}$ & 5,806 & 0.357 & 0.479 & 0 & 1 \\
\hline Monogamous & $\begin{array}{l}\text { Binary variable taking } 1 \text { if the household head is married to one wife and } \\
0 \text { otherwise }\end{array}$ & 5,806 & 0.510 & 0.500 & 0 & 1 \\
\hline Polygamous & $\begin{array}{l}\text { Binary variable taking } 1 \text { if the household head is married to more than } \\
\text { one wife and } 0 \text { otherwise }\end{array}$ & 5,806 & 0.150 & 0.357 & 0 & 1 \\
\hline $\begin{array}{l}\text { Gender } \\
(\text { Woman=1) }\end{array}$ & $\begin{array}{l}\text { Biological Sex of the household Head. Binary variable taking } 1 \text { if the } \\
\text { household head is a woman and } 0 \text { if a man. }\end{array}$ & 5,806 & 0.264 & 0.441 & 0 & 1 \\
\hline Land owing & Take value 1 if the household possesses a nonfarm land and 0 otherwise & 5,806 & 0.0164 & 0.127 & 0 & 1 \\
\hline Saving & $\begin{array}{l}\text { Indicator variable taking value } 1 \text { if the household has money saved in his } \\
\text { account and } 0 \text { otherwise }\end{array}$ & 5,806 & 0.120 & 0.324 & 0 & 1 \\
\hline Older person & Take value 1 if the household has an older person (more than 60 years) & 5,806 & 0.164 & 0.370 & 0 & 1 \\
\hline Credit refusal & Take value 1 if the household head demands credit and refused & 5,806 & 0.0369 & 0.188 & 0 & 1 \\
\hline Social network & $\begin{array}{l}\text { Indicator variable taking value } 1 \text { if the household is a member of a social } \\
\text { network and } 0 \text { otherwise. }\end{array}$ & 5,806 & 0.103 & 0.304 & 0 & 1 \\
\hline
\end{tabular}
assets such as land and belong to networks that allow them to cover risks to access credit from microfinance institutions collectively according to the public incentives mechanism.

Table 1. Descriptive statistics 


\begin{tabular}{|c|c|c|c|c|c|c|}
\hline Log of Income & $\begin{array}{l}\text { The logarithm of total permanent (wage and actual value of } \\
\text { household's assets) income in FCFA }\end{array}$ & 5,806 & 8.701 & 1.856 & 0 & 15.90 \\
\hline Credit & $\begin{array}{l}\text { Dependent variable. Take value } 1 \text { if the household has access to credit } \\
\text { from bank/IMF or the two and } 0 \text { otherwise }\end{array}$ & 5,806 & 0.0697 & 0.254 & 0 & 1 \\
\hline Business & $\begin{array}{l}\text { Take value } 1 \text { if the household has a non-agricultural enterprise in food } \\
\text { production, confection, construction, services, liberal activities, } \\
\text { restoration, artisanal and commerce) and } 0 \text { otherwise }\end{array}$ & 5,806 & 0.56217 & 0.49616 & 0 & 1 \\
\hline
\end{tabular}

Source: authors.

Note. * see also, Sodokin, 2021; Sodokin \& Nyatefe, 2021.

\section{Empirical Results and Discussion}

\subsection{Credit Access and Sample Selection Estimate}

The Maximum Likelihood methodology estimates the model. Columns $1 \& 2$ in Table 2 presents the results from estimating the reduced form using the Probit model. The results show that savings, land, social network, gender, and marital status increase credit attribution probability. The indication is those holders of some assets are more likely to be considered creditworthy by lenders. Being a social network member is regarded as social capital and increases the propensity to be eligible for microcredit. This implies that associations are considered collective risk insurance and a joint guarantee. Therefore, members of these social networks are more attractive to microfinance lenders. Columns $1 \& 2$ also show that polygamous households are more likely to access credit than their counterparts. Another important variable that is positively related to credit access is the level of education and gender. The results showed that female household heads are more likely to access credit from microfinance institutions, while gender does not significantly affect bank credit access. This can be explained by the fact that women engage in small business activities and often demand credit from microfinance than banks.

Furthermore, through microfinance institutions, women are the most beneficiaries of the Togolese government's credit incentive mechanism program. Having a secondary level of education is positively related to microcredit access. Education is an essential factor that helps to understand critical things easily. Therefore, it allows individuals to think critically and make rational decisions (Chinnadurai, 2005). So lenders from microfinance positively evaluate borrowers' education level who generally cannot signal the quality of information or provide adequate collateral to alleviate the asymmetric information problem.

Table 2. Access to (credit): Probit regression. Marginal effects (dy/dx)

\begin{tabular}{|c|c|c|c|c|}
\hline & (1) & (2) & (3) & (4) \\
\hline VARIABLES & $\begin{array}{l}\text { Borrowing ( }=1 \text { if household } \\
\text { applied and got credit, =0 if } \\
\text { the household did not apply } \\
\text { and missing if the application } \\
\text { was rejected }\end{array}$ & $\begin{array}{l}\text { Borrowing from MFI (=1 if } \\
\text { household applied and } \\
\text { credit, =0 if the household } \\
\text { did not apply and missing if } \\
\text { the application was denied) }\end{array}$ & $\begin{array}{l}\text { Borrowing from Bank (=1 if } \\
\text { household applied and got } \\
\text { credit, }=0 \text { if the household did } \\
\text { not apply and missing if the } \\
\text { application was rejected) }\end{array}$ & $\begin{array}{l}\text { credit exclusion reported } \\
(=1 \text { if excluded from } \\
\text { sample and }=0 \text { if } \\
\text { included in the sample })\end{array}$ \\
\hline \multirow[t]{2}{*}{ Household Age } & -0.0151 & 0.00175 & -0.0658 & 0.0156 \\
\hline & $(0.0243)$ & $(0.0262)$ & $(0.0516)$ & $(0.0224)$ \\
\hline \multirow[t]{2}{*}{ Age square } & 0.000158 & $3.80^{\mathrm{e}}-05$ & 0.000420 & -0.000145 \\
\hline & $(0.000242)$ & $(0.000261)$ & $(0.000502)$ & $(0.000224)$ \\
\hline \multirow[t]{2}{*}{ Saving } & $1.034 * * *$ & $0.942 * * *$ & $1.471 * * *$ & $-1.062 * * *$ \\
\hline & $(0.145)$ & $(0.158)$ & $(0.230)$ & $(0.142)$ \\
\hline \multirow[t]{2}{*}{ Land owing } & $0.716^{*}$ & & $2.503 * * *$ & $-0.688 *$ \\
\hline & $(0.460)$ & & $(0.658)$ & $(0.432)$ \\
\hline \multirow[t]{2}{*}{ Social Network } & $0.489 * * *$ & $0.598 * * *$ & -0.182 & $-1.011 * * *$ \\
\hline & $(0.175)$ & $(0.179)$ & $(0.373)$ & $(0.150)$ \\
\hline \multirow{4}{*}{$\begin{array}{l}\text { Primary } \\
\text { education } \\
\text { Secondary } \\
\text { education }\end{array}$} & 0.230 & 0.0620 & -0.00929 & -0.136 \\
\hline & $(0.158)$ & $(0.172)$ & $(0.352)$ & $(0.145)$ \\
\hline & 0.225 & $0.302 *$ & -0.573 & -0.142 \\
\hline & $(0.170)$ & $(0.178)$ & $(0.610)$ & $(0.157)$ \\
\hline \multirow{2}{*}{$\begin{array}{l}\text { University } \\
\text { education }\end{array}$} & -0.164 & -0.125 & -0.115 & 0.261 \\
\hline & $(0.294)$ & $(0.313)$ & $(0.468)$ & $(0.280)$ \\
\hline \multirow[t]{2}{*}{ Size } & 0.0220 & 0.0275 & 0.0541 & -0.00523 \\
\hline & $(0.0228)$ & $(0.0248)$ & $(0.0530)$ & $(0.0217)$ \\
\hline
\end{tabular}




\begin{tabular}{|c|c|c|c|c|}
\hline Lome & $\begin{array}{l}0.103 \\
(0.194)\end{array}$ & $\begin{array}{l}-0.0156 \\
(0.207)\end{array}$ & $\begin{array}{l}0.681 \\
(0.518)\end{array}$ & $\begin{array}{l}-0.123 \\
(0.178)\end{array}$ \\
\hline Plateaux & $\begin{array}{l}0.173 \\
(0.221)\end{array}$ & $\begin{array}{l}0.0487 \\
(0.234)\end{array}$ & $\begin{array}{l}1.009^{* *} \\
(0.479)\end{array}$ & $\begin{array}{l}-0.260 \\
(0.191)\end{array}$ \\
\hline Central & $\begin{array}{l}-0.248 \\
(0.251)\end{array}$ & $\begin{array}{l}-0.255 \\
(0.265)\end{array}$ & $\begin{array}{l}0.672 \\
(0.445)\end{array}$ & $\begin{array}{l}0.0652 \\
(0.214)\end{array}$ \\
\hline Kara & $\begin{array}{l}-0.00948 \\
(0.219)\end{array}$ & $\begin{array}{l}-0.153 \\
(0.232)\end{array}$ & $\begin{array}{l}1.241 * * * \\
(0.426)\end{array}$ & $\begin{array}{l}0.210 \\
(0.213)\end{array}$ \\
\hline Savanes & $\begin{array}{l}-0.216 \\
(0.254)\end{array}$ & $\begin{array}{l}-0.197 \\
(0.267)\end{array}$ & & $\begin{array}{l}-0.0340 \\
(0.226)\end{array}$ \\
\hline Rural & $\begin{array}{l}0.0549 \\
(0.154)\end{array}$ & $\begin{array}{l}0.0341 \\
(0.160)\end{array}$ & $\begin{array}{l}-0.0723 \\
(0.386)\end{array}$ & $\begin{array}{l}-0.162 \\
(0.140)\end{array}$ \\
\hline $\begin{array}{l}\text { Gender } \\
\text { (woman=1) }\end{array}$ & $\begin{array}{l}0.304^{*} \\
(0.161)\end{array}$ & $\begin{array}{l}0.327 * \\
(0.172)\end{array}$ & $\begin{array}{l}0.249 \\
(0.437)\end{array}$ & $\begin{array}{l}-0.201 \\
(0.155)\end{array}$ \\
\hline Sick & $\begin{array}{l}-0.245^{*} \\
(0.142)\end{array}$ & $\begin{array}{l}-0.154 \\
(0.149)\end{array}$ & $\begin{array}{l}-0.672 * \\
(0.398)\end{array}$ & $\begin{array}{l}-0.0172 \\
(0.122)\end{array}$ \\
\hline Log of Income & $\begin{array}{l}0.00166 \\
(0.0184)\end{array}$ & $\begin{array}{l}-0.00473 \\
(0.0186)\end{array}$ & $\begin{array}{l}-0.0146 \\
(0.0427)\end{array}$ & $\begin{array}{l}-0.0199 \\
(0.0193)\end{array}$ \\
\hline Monogamous & $\begin{array}{l}-0.0674 \\
(0.141)\end{array}$ & $\begin{array}{l}-0.121 \\
(0.153)\end{array}$ & $\begin{array}{l}0.0418 \\
(0.350)\end{array}$ & $\begin{array}{l}0.203 \\
(0.128)\end{array}$ \\
\hline Polygamous & $\begin{array}{l}0.364 * \\
(0.206)\end{array}$ & $\begin{array}{l}0.392 * \\
(0.213)\end{array}$ & & $\begin{array}{l}-0.273 \\
(0.198)\end{array}$ \\
\hline Constant & $\begin{array}{l}-1.656^{* * * *} \\
(0.618)\end{array}$ & $\begin{array}{l}-2.121^{* * * *} \\
(0.635)\end{array}$ & $\begin{array}{l}-1.768 \\
(1.409)\end{array}$ & $\begin{array}{l}1.633^{* * * *} \\
(0.578)\end{array}$ \\
\hline Observations & 1,067 & 1,059 & 857 & 1,067 \\
\hline
\end{tabular}

\subsection{Propensity Score Distribution}

Figure 1 shows the kernel density plots for the entire treatment and control groups' estimated propensity scores. According to figure 2, the credit participant households' distribution is slightly shifted to the right, indicating that these households have a higher propensity score than the non-participant households. This means that the beneficiary households are more likely to participate in the program than others. I balance them because the two groups differ on the basic covariates. Results show that the participant's kernel density plots and non-participant households overlap perfectly, indicating that the two groups balanced the propensity scores successfully.

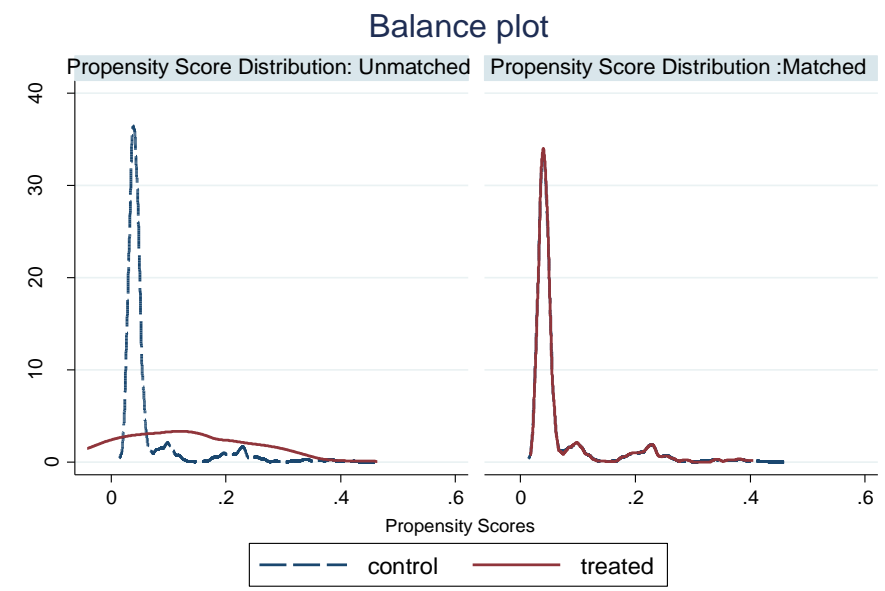

Figure 1. Propensity score distribution

Source: author from EHCVM Data.

\subsection{Covariates Balances}

To ensure the balancing property for the basic covariates used in calculating propensity scores when balancing the two groups, we add a dot plot to compare the standardized mean differences between the unmatched 
intervention and the control groups at baseline full sample (Figure 3). The dark-filled circles represent the mean difference between the unmatched intervention and the control groups at baseline. The crosses represent the mean difference between the matched intervention (the beneficiary and no beneficiary households) groups at the baseline. Standardized differences in the selected covariates are evident in our sample. But after matching, the mean difference is close to zero. Then, we evidence that the beneficiary and non-beneficiary households were balanced successfully on all the key covariates shown below.

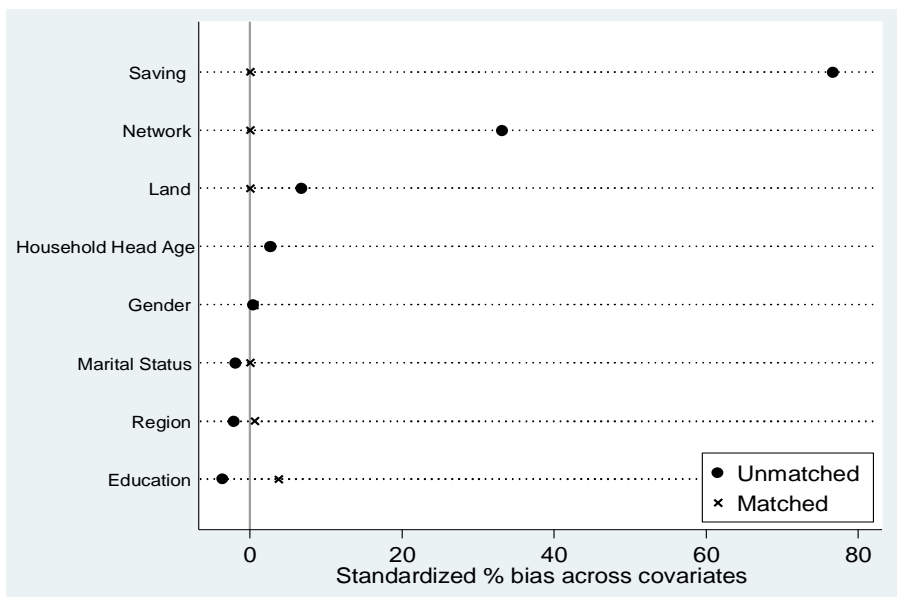

Figure 2. Dots plots showing the success of propensity score matching for the mean of the key variables Source: author from EHCVM Data.

\subsection{Investment Response to Credit Demand Under Alternative Assumptions}

Table 3 presents the results from estimating the impact of credit on a household's non-farm enterprises considering the whole sample. Our results revealed that access to credit did not significantly affect a household's likelihood to possess a non-farm firm.

Table 3. PSM estimates, impacts of credit access (Without a distinction between banks and Microfinance institutions) on household's business activities

\begin{tabular}{lcccc}
\hline Outcome variable & \multicolumn{3}{c}{ Impacts (treatment is credit access) } \\
\cline { 2 - 5 } & $\mathrm{NN}$ & Stratification & Radius & Kernel \\
\hline Business (Total) & -0.045 & -0.021 & -0.019 & -0.019 \\
& $(0.035)$ & $(0.026)$ & $(0.025)$ & $(0.023)$ \\
Food production & -0.025 & -0.010 & -0.011 & -0.010 \\
& $(0.029)$ & $(0.020)$ & $(0.019)$ & $(0.020)$ \\
Clothing & -0.009 & -0.002 & -0.009 & -0.003 \\
& $(0.015)$ & $(0.011)$ & $(0.011)$ & $(0.011)$ \\
Construction & 0.011 & -0.006 & -0.009 & -0.005 \\
& $(0.016)$ & $(0.012)$ & $(0.012)$ & $(0.012)$ \\
Liberal & -0.015 & 0.003 & -0.000 & 0.003 \\
& $(0.016)$ & $(0.007)$ & $(0.007)$ & $(0.008)$ \\
Services & -0.009 & -0.002 & -0.003 & -0.002 \\
& $(0.017)$ & $(0.012)$ & $(0.011)$ & $(0.011)$ \\
Catering & -0.008 & -0.008 & -0.010 & -0.008 \\
& $(0.009)$ & $(0.006)$ & $(0.006)$ & $(0.006)$ \\
handicraft & 0.008 & -0.008 & -0.004 & -0.007 \\
Trade & $(0.021)$ & $(0.016)$ & $(0.016)$ & $(0.018)$ \\
& 0.011 & 0.002 & 0.010 & 0.003 \\
\end{tabular}

5.4.1 Impact of Credit Access From Banks on Household's Investment in the Nonfarm Business

According to the results shown in table 4 below, credit access from banks did not significantly affect households' small businesses except confection, where the impact is negative. The evidence here is that some households borrowed money from banks to invest in activities like confection, which did not last in time. 
Table 4. PSM estimates, impacts of credit from banks on household's business activities

\begin{tabular}{|c|c|c|c|c|}
\hline \multirow[t]{2}{*}{ Outcome variable } & \multicolumn{4}{|c|}{ Impacts (treatment is credit access from Banks) } \\
\hline & $\mathrm{NN}$ & Stratification & Radius & Kernel \\
\hline \multirow[t]{2}{*}{ Business (Total) } & -0.038 & 0.006 & 0.005 & 0.015 \\
\hline & $(0.100)$ & $(0.00)$ & $(0.070)$ & $(0.066)$ \\
\hline \multirow[t]{2}{*}{ Food production } & -0.077 & 0.004 & 0.028 & 0.041 \\
\hline & $(0.091)$ & $(0.00)$ & $(0.058)$ & $(0.061)$ \\
\hline \multirow[t]{2}{*}{ Clothing } & -0.038 & -0.020 & $-0.033^{*}$ & $-0.032 * * *$ \\
\hline & $(0.041)$ & $(0.00)$ & $(0.020)$ & $(0.018)$ \\
\hline \multirow[t]{2}{*}{ Construction } & 0.058 & 0.023 & 0.008 & 0.009 \\
\hline & $(0.043)$ & $(0.00)$ & $(0.038)$ & $(0.036)$ \\
\hline \multirow[t]{2}{*}{ Liberal } & 0.038 & 0.042 & 0.037 & 0.037 \\
\hline & $(0.039)$ & $(0.00)$ & $(0.033)$ & $(0.028)$ \\
\hline \multirow[t]{2}{*}{ Services } & 0.038 & 0.023 & 0.019 & 0.019 \\
\hline & $(0.048)$ & $(0.00)$ & $(0.00)$ & $(0.038)$ \\
\hline \multirow[t]{2}{*}{ Catering } & -0.019 & 0.000 & -0.003 & -0.002 \\
\hline & $(0.035)$ & $(0.00)$ & $(0.020)$ & $(0.020)$ \\
\hline \multirow[t]{2}{*}{ handicraft } & -0.058 & -0.037 & -0.028 & -0.032 \\
\hline & $(0.065)$ & $(0.00)$ & $(0.038)$ & (0.039) \\
\hline \multirow[t]{2}{*}{ Trade } & 0.000 & -0.044 & -0.051 & -0.053 \\
\hline & $(0.067)$ & $(0.00)$ & $(0.046)$ & $(0.045)$ \\
\hline
\end{tabular}

Robust standard errors in parentheses; *** $\mathrm{p}<0.01, * * \mathrm{p}<0.05, * \mathrm{p}<0.1$

\subsubsection{Impact of Borrowing from Microfinance Institutions on Households' Investment in Non-Farm Activities}

According to the results (Table 5), compared to the non-participant households, having access to credit increased the probability to invest in a non-farm business by $3.2 \%$ in construction, between $4.2 \%$ and $4.4 \%$ in trade, and about $3.2 \%$ in services. In other words, sectors benefiting from access to credit are services, building, and trade. Construction includes business at home or elsewhere in house building (masonry, electricity, plumbing) or carpentry (furniture, beds, doors, and windows) made of wood or metal such as iron or aluminum.

Indeed, the construction sector is one of Togo's most flourishing industries because, by nature, every Togolese aspires to build his own home. Therefore, households who already own non-agricultural businesses use microcredits as a credit to strengthen their activity. Similarly, other households with skills in the field will also use credit to start their activity.

The second sector benefiting from the positive impacts of microcredit is the service sector. This branch of activity includes cab service, motorcycle cab, repair and maintenance, car washing, door-to-door sales agents, telephone booth, and word processing and photocopying services. The results suggest that households receiving credit from microfinance institutions can invest in this sector compared to non-beneficiaries. Two implications flow from these results. First, the problem of moral hazard would be less in this sector than in others. In other words, credits recipients invest the credit obtained in activities in this sector. Second, households would find this branch more promising than other branches and prefer to invest the credits obtained in these activities. Also, most motorcycle cab drivers get credit to purchase motorcycles.

The results also reveal that trade is the activity with the most significant reliance on microcredit. In other words, most of the microcredits obtained are directed towards creating a commercial enterprise such as stores, the sale of construction materials, computer equipment, telephone cards, etc. Several factors may explain this result: First, since the small business does not require extensive professional training, it is easier and quicker for households to get involved. Second, women are the most represented in small businesses in Togo. Also, they are the most privileged in the public financial incentive mechanism that facilitates their access to microcredit. This shows that easy access to credit has a more significant impact on creating income-generating activities for beneficiary households. These results are very encouraging because microcredit allows households to become financially independent by exploring their skills, knowledge, and capacity to plan.

The results in Table 5 show that entrepreneurship in crafts (sales of art objects, carpets, jewelry), hairdressing, catering, and professions (doctor, traditional practitioner, lawyer, architect, design engineering) are negatively affected by access to credit. Compared to non-beneficiaries, households with access to microcredit have an average $12 \%$ chance of not being self-employed. They are between $13 \%$ and $14 \%$ less likely to be employed in 
the restaurant business and between $32 \%$ and $39 \%$ less likely to be engaged in crafts. These results imply that microcredit does not increase household investment in these activities.

Table 5. PSM estimates, impact of microcredit on business activities

\begin{tabular}{|c|c|c|c|c|}
\hline \multirow[t]{2}{*}{ Outcome variable } & \multicolumn{4}{|c|}{ Impacts (treatment is credit access from Microfinance Institution) } \\
\hline & $\mathrm{NN}$ & Stratification & Radius & Kernel \\
\hline \multirow[t]{2}{*}{ Business (Total) } & 0.048 & 0.007 & 0.006 & 0.008 \\
\hline & $(0.044)$ & $(0.031)$ & $(0.031)$ & $(0.032)$ \\
\hline \multirow[t]{2}{*}{ Food production } & 0.014 & 0.011 & 0.015 & 0.014 \\
\hline & $(0.035)$ & $(0.025)$ & $(0.025)$ & $(0.022)$ \\
\hline \multirow[t]{2}{*}{ Clothing } & -0.018 & 0.009 & -0.001 & 0.002 \\
\hline & $(0.022)$ & $(0.014)$ & $(0.014)$ & $(0.014)$ \\
\hline \multirow[t]{2}{*}{ Construction } & $0.032 * * *$ & -0.012 & -0.014 & -0.015 \\
\hline & $(0.016)$ & $(0.014)$ & $(0.014)$ & $(0.013)$ \\
\hline \multirow[t]{2}{*}{ Liberal } & -0.007 & -0.010 & $-0.012 * * *$ & $-0.012 * * *$ \\
\hline & $(0.011)$ & $(0.007)$ & $(0.007)$ & $(0.006)$ \\
\hline \multirow[t]{2}{*}{ Services } & $0.032 * * *$ & -0.002 & -0.003 & -0.002 \\
\hline & $(0.017)$ & $(0.014)$ & $(0.014)$ & $(0.012)$ \\
\hline \multirow[t]{2}{*}{ Catering } & -0.018 & $-0.013^{* * * *}$ & $-0.013^{* * *}$ & $-0.014 * * *$ \\
\hline & $(0.011)$ & $(0.007)$ & $(0.007)$ & $(0.006)$ \\
\hline \multirow[t]{2}{*}{ handicraft } & -0.021 & $-0.039 * * *$ & $-0.032 * * *$ & $-0.032 * *$ \\
\hline & $(0.026)$ & $(0.017)$ & $(0.017)$ & $(0.018)$ \\
\hline \multirow[t]{2}{*}{ Trade } & 0.051 & $0.042 *$ & $0.044^{* *}$ & $0.043^{* *}$ \\
\hline & $(0.034)$ & $(0.025)$ & $(0.025)$ & $(0.021)$ \\
\hline
\end{tabular}

Robust standard errors in parentheses; *** $\mathrm{p}<0.01, * * \mathrm{p}<0.05, * \mathrm{p}<0.1$.

Indeed, the liberal professions considered here require higher education and specialized skills. Those who practice these professions are naturally non-vulnerable and have more opportunities to access Bank credit. Consequently, these people would not resort to small microcredit to finance their activities. The negative impact of microfinance on handicrafts would essentially be due either to the problem of moral hazard or to a combination of activities. The moral hazard here consists in diverting the purpose of the credit. It is likely that these households would report obtaining credit to either start up or expand existing activities in the sector but would divert the credit to other purposes, which would lead to the disappearance of the activity later on. The second implication is the combination of activities. Typically, households engaged in these activities to diversify their incomes combine retail trade with handicrafts. As a result, it may be that the credit obtained finances the commercial activity rather than the craft activity itself. In this case, the negative impact would be due to the redirection of credit to the retail sector deemed more profitable. Therefore, the effect on households seems to be more tangible.

Other factors, such as the household's potential, age, and managerial skills, may determine the impact. Indeed, the viability of any business depends on the promoter's interest, skills, and potential. Since microcredits are generally granted to those who typically do not have adequate training, this reduces business survival chances (Das, 2000). Similarly, risk-taking can be associated with age, as the youngest and most vigorous would be more inclined to take entrepreneurial risks than the oldest. Business success also requires managerial skills such as taking risks and introducing innovation, planning, etc. (Das, 2000). Generally, these skills are lacking for those vulnerable households that are entrepreneurial. All of these factors could reverse the positive impact that accesses to credit could have on households' entrepreneurial decisions and the survival of their income-generating activities.

\subsubsection{Impact of Credit Access on Farm Enterprises}

To measure the impact of access to credit on household agricultural entrepreneurship, I undertook the exact estimates using propensity scores. The results are shown in Table 6 below. Overall, the percentage of households with access to credit is $44.7 \%$, and $51.4 \%$ of credit beneficiaries' households are more likely to have an agricultural business than non-beneficiaries. This implies that facilitating access to credit for households could significantly impact the development of the farming sector. These results are plausible, given that $70 \%$ of Togo's population is involved in the agricultural industry (INSEED, 2019). 
Table 6. PSM, credit impact on farm activities

\begin{tabular}{lllll}
\hline Outcome variable & \multicolumn{4}{l}{ Impacts (treatment is the demand for credit without distinction between Banks and Microfinance) } \\
\cline { 2 - 5 } & $\mathrm{NN}$ & Stratification & Radius & Kernel \\
\hline Agricultural activities & $0.447^{* * *}$ & $0.422^{* * *}$ & $0.446^{* * *}$ & $0.514^{* * *}$ \\
& $(0.031)$ & $(0.011)$ & $(0.009)$ & $(0.023)$ \\
\hline
\end{tabular}

Robust standard errors in parentheses; *** $\mathrm{p}<0.01, * * \mathrm{p}<0.05, * \mathrm{p}<0.1$.

I then distinguished between the source of credits and displayed the results in Table 7. The results suggest that microcredit has a more significant impact on beneficiaries than loans from banks. These results are justified since most of the agricultural population is rural, with limited access to banks credit. Furthermore, government policies to facilitate credit in the agricultural sector remove constraints and barriers for smallholder farmers to access credit. These results show that the relevance of financing for the agricultural industry, especially for smallholders who make a significant contribution to national agricultural production, is very high.

Table 7. PSM estimates: Demand for credit from Banks and Microfinance and impact on farm activities

\begin{tabular}{lllllllll}
\hline \multirow{2}{*}{$\begin{array}{l}\text { Outcome } \\
\text { variable }\end{array}$} & \multicolumn{6}{c}{ Impacts (treatment is Banks and Microfinance demand for credit) } \\
\cline { 2 - 9 } & $\mathrm{NN}$ & Stratification & Radius & Kernel & NN & Stratification & Radius & Kernel \\
\hline \multirow{nyyyyyyyy}{*}{ Agricultural } & $0.388^{* * *}$ & $0.433 * * *$ & $0.407 * * *$ & $0.537^{* * *}$ & $0.255^{* * *}$ & 0.407 & $0.396^{* * * *}$ & $0.416^{* * * *}$ \\
activities & $(0.038)$ & $(0.011)$ & $(0.008)$ & $(0.040)$ & $(0.000)$ & - & $(0.011)$ & $(0.024)$ \\
\hline
\end{tabular}

Robust standard errors in parentheses; *** $\mathrm{p}<0.01, * * \mathrm{p}<0.05, * \mathrm{p}<0.1$.

\section{Concluding Remarks}

I used the Propensity Score Matching Method to show that access to credit significantly impacts the dynamics of small-scale household activities in Togo, particularly agricultural activities. Although the conventional credit market exists, most households apply for credit from microfinance institutions to finance their small business. These households are generally those that are excluded from the traditional credit market. Access is explained for households who receive credit from conventional banks by having savings in their account and holding an asset such as land. The geographical factor such as region also explains households' access to credit from banks. On the other hand, a fragile state of health reduces the likelihood of having access to credit from banks in Togo. Microcredit is conditional on savings, membership to a social group, level of education, and gender.

These results imply that the most affluent small business owners benefit from conventional banks' credit, while the most disadvantaged are more likely to access microfinance institutions. This further supports the hypothesis that bank credit is more targeted to the wealthiest households and that bank lenders tend to offer loans to the most advantaged households. Another impressive result is that the credit market's exclusion is associated with the non-existence of savings, from not holding assets to not being a social group member. The analysis also showed that microcredit has a more significant impact in financing business in construction, services, trade, and agriculture. Formal banks credit would play a more substantial role in agriculture, but the effect is still negligible.

\section{References}

Abadie, A., \& Imbens, G. W. (2011). Bias-corrected matching estimators for average treatment effects. Journal of Business \& Economic Statistics, 29(1), 1-11. https://doi.org/10.1198/jbes.2009.07333

Agbola, F. W., Acupan, A., \& Mahmood, A. (2017). Does microfinance reduce poverty? New evidence from Northeastern Mindanao, the Philippines. Journal of Rural Studies, 50, 159-171. https://doi.org/10.1016/j.jrurstud.2016.11.005

Alimukhamedova, N. (2019). The microfinance promise — can it be kept? A macro perspective. Development Policy Review, 37(6), 812-842. https://doi.org/10.1111/dpr.12412

Bangoura, L., Mbow, M. K., Lessoua, A., \& Diaw, D. (2016). Impact of microfinance on poverty and inequality: A heterogeneous panel causality analysis. Revue d'Economie Politique, 126(5), 789-818. https://doi.org/10.3917/redp.265.0789

Becker, S. O., \& Ichino, A. (2002). Estimation of average treatment effects based on propensity scores. The Stata Journal, 2(4), 358-377. https://doi.org/10.1177/1536867X0200200403 
Bel hadj Miled, K., \& Ben, R. JE. (2018). Can Microfinance Help to Reduce Poverty? A Review of Evidence for Developing Countries. J Knowl Econ., 9, 613-635. https://doi.org/10.1007/s13132-015-0348-2

Belwal, R., Tamiru, M., \& Singh, G. (2012). Microfinance and Sustained Economic Improvement: Women Small-Scale Entrepreneurs in Ethiopia. Journal of International Development, 24(S1), 84-99. https://doi.org/10.1002/jid.1782

Bruhn, M., \& Love, I. (2014). The real impact of improved access to finance: Evidence from Mexico. The Journal of Finance, 69(3), 1347-1376. https://doi.org/10.1111/jofi.12091

Cameron, A. C., \& Trivedi, P. K. (2010). Microeconometrics using Stata (revised ed.). Number musr in Stata Press books. StataCorp LP.

Cameron, A. C., \& Trivedi, P. K. (2005). Microeconometrics: Methods and applications. Cambridge university press. https://doi.org/10.1017/CBO9780511811241

Caunedo, J., \& Elisa, K. (2019). Capital Obsolescence and Agricultural Productivity. Working paper.

Chinnadurai, R. (2005). Women Entrepreneurship and Service Sector. Kurukshetra, 54(1), 19-24.

Couchoro, M., \& Gbandi, T. (2018). Microfinance et pauvreté multidimensionnelle dans la Communauté économique des États de l'Afrique de l'Ouest (CEDEAO) : une perspective macro-économique. Mondes en Développement, (1), 147-164. https://doi.org/10.3917/med.181.0147

Donou-Adonsou, F., \& Sylwester, K. (2016). Financial development and poverty reduction in developing countries: new evidence from Banks and Microfinance Institutions, Review of Development Finance, 6(1), 82-92. https://doi.org/10.1016/j.rdf.2016.06.002

Duong, P. B., \& Izumida, Y. (2002). Rural development finance in Vietnam: A microeconometric analysis of household surveys. World Development, 30(2), 319-335. https://doi.org/10.1016/S0305-750X(01)00112-7

Ghalib, A. K., Malki, I., \& Imai, K. S. (2011). The impact of microfinance and its role in easing poverty of rural households: Estimations from Pakistan. Kobe University, 9(1), 1-37.

Khandker, S. R. (1996). Grameen Bank: Impact, costs, and program sustainability. Asian Development Review, 141(I), 97-130. http://hdl.handle.net/11540/5371

Khandker, S. R., \& Faruqee, R. R. (2003). The impact of farm credit in Pakistan. Agricultural Economics, 28(3), 197-213. https://doi.org/10.1111/j.1574-0862.2003.tb00138.x

Kochar, A. (1997). An empirical investigation of rationing constraints in rural credit markets in India. Journal of Development Economics, 53(2), 339-371. https://doi.org/10.1016/S0304-3878(97)00020-5

Nader, Y. F. (2008). Microcredit and the socio-economic well-being of women and their families in Cairo. The Journal of Socio-Economics, 37(2), 644-656. https://doi.org/10.1016/j.socec.2007.10.008

Pitt, M. M., \& Khandker, S. R. (1996). Household and intrahousehold impact of the Grameen Bank and similar targeted credit programs in Bangladesh. The World Bank. https://doi.org/10.1596/0-8213-3594-4

Quach, H., \& Mullineux, A. (2007). The impact of access to credit on household welfare in rural Vietnam. $\begin{array}{lllll}\text { Research in Accounting in Emerging } & \text { Economies, }\end{array}$ https://doi.org/10.1016/S1479-3563(06)07014-9

Raihan, S., Osmani, S. R., \& Khalily, M. B. (2017). The macro impact of microfinance in Bangladesh: A CGE analysis. Economic Modelling, 62, 1-15. https://doi.org/10.1016/j.econmod.2017.01.002

Rosenbaum, P. R., \& Rubin, D. B. (1983). The central role of the propensity score in observational studies for causal effects. Biometrika, 70(1), 41-55. https://doi.org/10.1093/biomet/70.1.41

Rubin, D. B. (1973). The use of matched sampling and regression adjustment to remove bias in observational studies. Biometrics, 185-203. https://doi.org/10.2307/2529685

Sodokin, K. (2007). Banques et Microbanques dans les Pays en Voie de Développement: Analyse de leur Complémentarité et Perspectives de Réformes. Thèse de Doctorat, Dijon.

Sodokin, K., \& Nyatefe, V. (2021). Cash transfers, climate shocks vulnerability and households' resilience in Togo. Discover Sustainability, 2, 3. https://doi.org/10.1007/s43621-021-00010-5

Sodokin, K. (2021). Comparative analysis, cash transfers, household investment and inequality reduction in Togo. Applied Economics, 53, 2598-2614. https://doi.org/10.1080/00036846.2020.1863324

Sodokin, K., \& Donou-Adonsou, C. (2010). Banks, Microfinance Institutions and Economic Growth in the West 
African Economic and Monetary Union. African Development Review, 22(4), 495-510. https://doi.org/10.1111/j.1467-8268.2010.00245.x

Yadav, S., Otsuka, K., \& David, C. C. (1992). Segmentation in rural financial markets: The case of Nepal. World Development, 20(3), 423-436. https://doi.org/10.1016/0305-750X(92)90033-R

Zeller, M. (1994). Determinants of credit rationing: A study of informal lenders and formal credit groups in Madagascar. World Development, 22(2), 1895-1907. https://doi.org/10.1016/0305-750X(94)90181-3

\section{Copyrights}

Copyright for this article is retained by the author(s), with first publication rights granted to the journal.

This is an open-access article distributed under the terms and conditions of the Creative Commons Attribution license (http://creativecommons.org/licenses/by/4.0/). 